\title{
Productivity and the Survival Rate after Winter Management of Seven Tropical Forage Accessions in Subtropical Region of China
}

\author{
Chengxin He${ }^{1}$, Ling Mo1, Yuqing Huang1* ${ }^{*}$ Zhongfeng Zhang1, Michael Hare², Danjuan Zen1, \\ Gaozhong Pu${ }^{1}$ \\ ${ }^{1}$ Guangxi Key Laboratory of Plant Conservation and Restoration Ecology in Karst Terrain, Guangxi Institute of Botany, CAS, \\ Guilin, China \\ ${ }^{2}$ Faculty of Agriculture, Ubon Ratchathani University, Ubon Ratchathani, Thailand \\ Email: *hyqcoco@gxib.cn
}

How to cite this paper: He, C.X., Mo, L., Huang, Y.Q., Zhang, Z.F., Hare, M., Zen, D.J. and Pu, G.Z. (2017) Productivity and the Survival Rate after Winter Management of Seven Tropical Forage Accessions in Subtropical Region of China. Agricultural Sciences, 8, 451-464.

https://doi.org/10.4236/as.2017.85034

Received: February 21, 2017

Accepted: May 24, 2017

Published: May 27, 2017

Copyright $\odot 2017$ by authors and Scientific Research Publishing Inc. This work is licensed under the Creative Commons Attribution International License (CC BY 4.0).

http://creativecommons.org/licenses/by/4.0/

(c) (i) Open Access

\begin{abstract}
Forage production and quality of five tropical grass accessions (Guimu-1 hybrid elephant grass (PG1), Mulato II (M II), Ubon paspalum (PU), hybrid elephant grass (PH) and Reyan 11 paspalum (PR11)) and two tropical legume accessions (Reyan 5 stylo (SR5) and Ubon stylo (SU)) were evaluated in a field experiment in a subtropical area with hot summers and cold winters in Guangxi, China. Three forage stubble cover managements: no cover (CK), dry mass cover (MC) and plastic cover (PC) were applied at the end of the summer period to evaluate cold tolerance and accession survival over the winter. Photosynthesis measurements were taken from the forages in mid-summer. The results showed that PG1 accession produced significantly higher dry matter yields $\left(67.0 \mathrm{t} \cdot \mathrm{ha}^{-1}\right)$ than the other grass and legume accessions. Legume accessions SU and SR5 produced much less dry matter $\left(6.4-7.2 \mathrm{t} \cdot \mathrm{ha}^{-1}\right)$ compared to the grasses. M II, PU and PR11 contained the largest proportion of leaf. PG1 and PH showed good cold tolerance (survival rate $>85 \%$ ) under $-1^{\circ} \mathrm{C}$ conditions without any cover management. PR11 had better cold tolerance than PU. M II exhibited very poor winter survival under no cover and with massive cover, and only survived well under plastic cover. The two stylo accessions died completely under all winter cover management treatments. In the growing season, under a given photosynthesis photon flux density ( $P P F D)$ $=1500 \mu \mathrm{mol} \mathrm{m}^{-2} \mathrm{~s}^{-1}$, the net photosynthesis rate $P_{\mathrm{n}}$ of all the seven accessions was above $28 \mu \mathrm{mol} \mathrm{m} \mathrm{m}^{-2} \mathrm{~s}^{-1}$, of which hybrid elephant grass and M II were above $42 \mu \mathrm{mol} \mathrm{m} \mathrm{m}^{-2} \mathrm{~s}^{-1}$. Though these 7 tropical accessions yielded high production in the grow season, stylo and M II are sensitive to cold in subtropical region of Guangxi. The result suggests that PG1 and PU are good accessions and can be used as productive perennial pasture, while stylo and M II are
\end{abstract}


simply considered as annual one. Additionally, if paspalum was trained in cool region before being introduced to subtropical region, it may present both productivity and enhancive cold tolerance.

\section{Keywords}

Cold Tolerance, Production, Photosynthesis, Tropical Grasses, Winter Management

\section{Introduction}

Typical subtropical areas of Guangxi, China ( $\left.105^{\circ} 05^{\prime \prime}-111^{\circ} 32^{\prime \prime E}, 21^{\circ} 20^{\prime \prime}-26^{\circ} 02^{\prime \prime N}\right)$, experience hot summers $\left(>35^{\circ} \mathrm{C}\right)$ and cold winters (below $0^{\circ} \mathrm{C}$ or close to $0^{\circ} \mathrm{C}$ ), and a pronounced seasonal rainfall (70\% - 80\% between April to August), varying from 1200 - $2200 \mathrm{~mm}$ per annum. The summer energetic availability advances high productive tropical pasture species, such as Pennisetum, Paspalum, Brachiaria [1] [2] [3], to growth in subtropical area [4] [5], particular grass C4 plants, which prefer to warmer climates because their physiological processes are adversely affected by low temperature [6] [7]. Winter-spring low temperature is one of the most factors to limit the growth and productivity of plants [8] [9] and limit the geographical locations where cultivated species can be grown [10]. When extend the tropical pasture species to subtropical area, chilling injury of these pasture species during the winter are serious impact on productivity and sustainability, which greatly constrain livestock production.

High dry mater production and good quality would have been the great interest by livestock. Net photosynthesis is a characteristic constitutional feature of accessions and species of plant, high photosynthetic capacity, usually can be expressed high $\mathrm{CO}_{2}$ convert into organic matter biomass by photochemical process [11]. There are a number of perennial productive and good quality tropical pasture species that do grow in these subtropical areas, but their growth and production are usually limited by low winter temperatures [8] [9]. For example, the net photosynthesis rate $(\mathrm{Pn})$ of Stylosanthes guianensis might decrease dramatically under temperature below $28^{\circ} \mathrm{C}$ down to $8^{\circ} \mathrm{C}$ [12]; while Pn of Elephant grass (Pennisutum purpureum) did not show decrease when temperature drop from $25^{\circ} \mathrm{C}$ to $14^{\circ} \mathrm{C}$ [8]. Therefore, to obtain a good appreciation of pasture species adaptation/suitability with high productivity, a winter-cold tolerance germplasm collection under a broad management program should be tested in a typical soil and climatic zones. However, little information of this case is available in Guangxi subtropical area where many farmers have been trying to introduce tropical pasture species in recent years.

Our objectives in this study were to evaluate five tropical grass accessions and two tropical legume accessions which have been found to be productive in northeast Thailand, on Hainan Island, China, and in south Guangxi, China by establishing a field trial to study their dry matter production and quality, photo- 
synthesis and their cold tolerance and winter persistence under different stubble cover management before the winter.

\section{Materials and Methods}

\subsection{Materials}

Materials include Guimu-1 hybrid elephant grass (PG1, Pennisetum americanum L. $\times$ P. purpureum Schumach $\times$ P. purpureum Schumach) from Nanning, Guangxi (Liang 1999); Mulato II [MII, Brachiaria ruziziensis Germain \& Evrard $\times$ B. decumbens Stapf $\times$ B. brizantha (A. Rich.) Stapf], Ubon paspalum (PU, Paspalum atratum Swallen), Ubon stylo [SU, Stylosanthes guianensis (Aublet) Swartz $\times$ var. vulgaris M. B. Ferreira \& Sousa Costa $\times$ var. pauciflora M. B. Ferreira \& Sousa Costa [13] [14] [15] from Thailand; and hybrid elephant grass (PH, Pennisetum americanum L. $\times$ P. purpureum Schumach), Reyan 11 paspalum (PR11, Paspalum atratum Swallen), Reyan 5 stylo [Stylosanthes guianensis (Aublet) Swartz. var. guianensis [5] [16] [17] from Hainan island China.

\subsection{Site Description}

The field trial was conducted at the Guangxi Institute of Botany, Yanshan town, $20 \mathrm{~km}$ south of Guilin City, Guangxi, China $\left(110^{\circ} 18^{\prime \prime} \mathrm{E}, 25^{\circ} 04^{\prime \prime N}\right)$. The average annual temperature is $19.3^{\circ} \mathrm{C}$ and the annual rainfall $1900 \mathrm{~mm}$ (Figure $1(\mathrm{a})$ ). The wet season (70\% of total rainfall) is in the summer from April to August. The dry season begins in September and lasts through to February. Cold temperatures begin in November, dropping dramatically with onset of strong winds. On average, three days of daily-mean temperatures of $<0^{\circ} \mathrm{C}$ per year have occurred since 1951 , reaching a minimum of $-4.9^{\circ} \mathrm{C}$.

The field trial site was on clay Haplic Acrisol soil previously planted in peach trees from 2002-2006 and was waste land in 2007-2008. Soil samples to $10 \mathrm{~cm}$

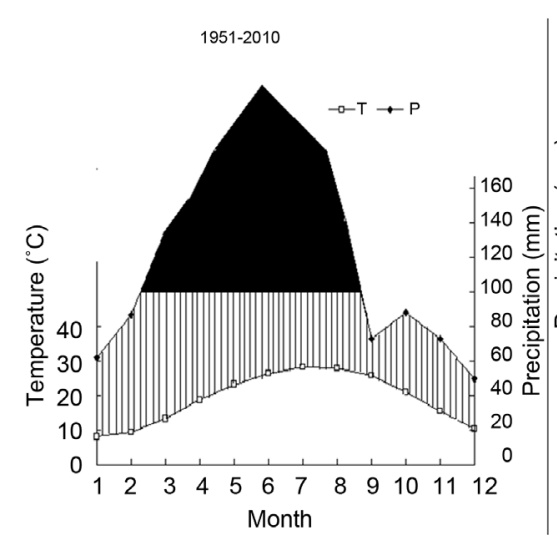

(a)

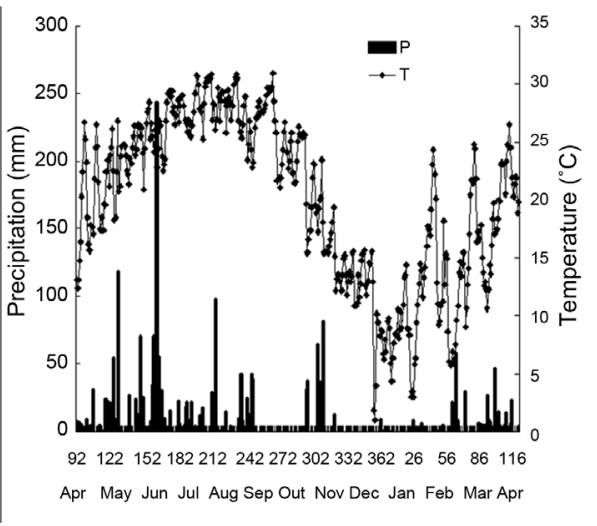

(b)

Figure 1. (a) Climatic diagram of Guilin over 55 yrs. Moist conditions are indicated if the temperature line is below the precipitation line (bar area) and very wet conditions are indicated if the precipitation $>100 \mathrm{~mm}$ (black area). $\mathrm{P}$ refers to precipitation and $\mathrm{T}$ refers to temperature; (b) temperature and precipitation at Guilin from April 2008 to April 2009. P refers to precipitation and $\mathrm{T}$ refers to temperature. 
depth, taken at sowing in May 2008, showed that the soil $\mathrm{pH}$ was 6.24 (water method), total $\mathrm{N}$ was $1.405 \mathrm{~g} \cdot \mathrm{kg}^{-1}$, total $\mathrm{P}$ was $0.9695 \mathrm{~g} \cdot \mathrm{kg}^{-1}$, total $\mathrm{K}$ was 7.475 $\mathrm{g} \cdot \mathrm{kg}^{-1}$, hydrate $\mathrm{N}$ was $150.5 \mathrm{mg} \cdot \mathrm{kg}^{-1}$, available $\mathrm{P}$ was $56.6 \mathrm{mg} \cdot \mathrm{kg}^{-1}$, available $\mathrm{K}$ was $47.7 \mathrm{mg} \cdot \mathrm{kg}^{-1}$ and total sulfur was $186 \mathrm{mg} \cdot \mathrm{kg}^{-1}$.

\subsection{Experimental Design}

Trail was initiated in April 2008. The seven accessions were planted in $2 \mathrm{~m} \times 3 \mathrm{~m}$ plots in a randomized design with three replications. On April 29 - 30, 2008, seeds of M II, Ubon paspalum, Reyan 11 paspalum, Ubon stylo and Reyan 5 stylo were sown in spacing of $20 \mathrm{~cm} \times 10 \mathrm{~cm}$ for the grasses and $10 \mathrm{~cm} \times 10 \mathrm{~cm}$ for legumes, and stem cuttings of Guimu 1 and hybrid elephant grasses were planted in $20 \mathrm{~cm} \times 10 \mathrm{~cm}$ spacing. Animal manure at $33,333 \mathrm{~kg} \cdot \mathrm{ha}^{-1}\left(20 \mathrm{~kg} \cdot \mathrm{plot}^{-1}\right)$ and compound fertilizer $(\mathrm{N}: \mathrm{P}: \mathrm{K}=15: 15: 15)$ at $500 \mathrm{~kg} \cdot \mathrm{ha}^{-1}\left(0.3 \mathrm{~kg} \cdot \mathrm{plot}^{-1}\right)$ were applied across each plot at planting. Urea at $333 \mathrm{~kg} \cdot \mathrm{ha}^{-1}\left(0.2 \mathrm{~kg} \cdot \mathrm{plot}^{-1}\right)$ was applied to each plot after every cutting harvest.

A cold tolerance and winter survival management trial was conducted on the same plots during the 2008-2009. Air temperatures references were taken at the Gantang vegetation monitoring site, $6 \mathrm{~km}$ away from the trial site. Following the last cutting harvest on $24^{\text {th }}$ November, 2008, a stubble height of $10 \mathrm{~cm}$ was left on all the plots. Each plot was divided into three equal areas and three treatments were applied: (1) No cover (CK); (2) Dry mass cover (MC) applied on $21^{\text {st }}$ December, 2008, the day before the weather forecast informed us that the Cold Wave Weather was arriving. Dry grass residues from the last harvest in November were used to cover the grass plots, but rice straw was used to cover the legume plots. Some soil was use to suppress the grass cover in case the grass was blown away by strong winds; (3) Plastic cover (PC). Plots were covered with plastic sheets on the same day as MC.

\subsection{Sampling and Measuring}

Dry matter cuts of the grass accessions were taken in August, September and November in 2008 and 2009, when their heights reached 1.0 - 1.5 m. Dry matter cuts of the two stylo accessions were taken in August and November of both years when they were dense and covered the soil completely. At each cut, three random $1 \mathrm{~m} \times 1 \mathrm{~m}$ quadrants were sampled at $5 \mathrm{~cm}$ above ground level in each plot. At the last cut in November 2008, samples were cut to $10 \mathrm{~cm}$ above ground level.

A $2 \mathrm{~kg}$ subsample per plot was oven dried at $80^{\circ} \mathrm{C}$ for $12 \mathrm{~h}$ and dry weight recorded. Air-dried samples taken on $30^{\text {th }}$ August and $24^{\text {th }}$ November in 2008 from each plot were cut into $2 \mathrm{~cm}$ lengths and were analyzed for crude protein and crude fibre and crude fat following the methods of the Chinese National Standard GB/T6432-1994, GB/T 6433-2006 and GB/6434-2006 [18]. Leaves and stems of samples cut on $24^{\text {th }}$ November, 2008, were separated and dried in the laboratory to determine their ratio. 
Photosynthesis measurements were taken from $12^{\text {th }}-18^{\text {th }}$ August, 2008. Gas exchange parameters (net photosynthesis rate $P_{\mathrm{n}}$, transpiration rate $T_{\mathrm{r}}$ and stomatal conductance rate $G_{s}$ ) was measured on the most recent fully expanded leaf of each plot at $1500 \mu \mathrm{mol} \mathrm{m} \mathrm{m}^{-2} \cdot \mathrm{s}^{-1}$. Then water use efficiency $W U E$ equal to $P_{\mathrm{n}} / T_{\mathrm{r}}$ ratio. Photosynthetic photon flux density $(P P F D)$ light levels were measured by a Li 6400-02B LED light chamber (Li-COR, Inc, USA). The photosynthetic rate of the grass accessions were measured on four samples per plot at 14 light intensities of PPFD obtained following the order 2200, 1800, 1500, 1200, 1000, 800, 600, $400,200,150,100,50,20,0 \mu \mathrm{mol} \mathrm{m}{ }^{-2} \cdot \mathrm{s}^{-1}$ to determine the light curve.

After winter cold tolerance management, on $10^{\text {th }}$ May, 2009, the survival (S) and the mortality $(\mathrm{M})$ of tufts of grasses and the area of mortality of the legume were surveyed.

\subsection{Statistic}

Survival rate $\left(R_{\mathrm{s}}\right)$ was then calculated by:

$$
R_{s}=S /(S+M) * 100 \%
$$

The photosynthesis rate response to light was fitted by the Mitscherlich function [19]:

$$
P_{n}=P_{\max }\left[1-\exp ^{-A q e(P P F D-L C P)}\right]
$$

where $P_{n}$ is the net photosynthesis rate; $P_{\max }$ the maximum photosynthesis rate, $\mathrm{A}_{\mathrm{qe}}$ corresponds to the initial slope of the curve at low light levels (0 - $200 \mu \mathrm{mol}$ $\mathrm{m}^{-2} \cdot \mathrm{s}^{-1}$ ); $L C P$ is the light compensation point (referring to the $\mathrm{x}$-intercept, when net photosynthesis is equal to zero), and $P P F D$ refers to the incident photosynthetic photon flux density. The light saturation point $(L S P)$ was defined as $90 \%$ of PPFD at $P_{\max }$ using Formulate (1) [20] [21].

The statistical program SPSS 13 was applied to analyze mean comparison between accessions and years under One-way ANOVA statistics with significant at the $P<0.05$ significant level.

\section{Results}

\subsection{Meteorological Data}

The highest temperature during the study was $38.2^{\circ} \mathrm{C}$ (average highest daily mean $30.8^{\circ} \mathrm{C}$ ) and the lowest $-1.0^{\circ} \mathrm{C}$ (average lowest daily mean $1.0^{\circ} \mathrm{C}$ ) (Figure $1(\mathrm{~b})$ ). Temperatures below zero only occurred for two days on $22^{\text {nd }}$ and $23^{\text {rd }}$ December, 2008, and the daily mean temperature then averaged $3^{\circ} \mathrm{C}$ until the middle of February. Temperatures rose rapidly in mid February to $27^{\circ} \mathrm{C}-30^{\circ} \mathrm{C}$, dropped again in March to below $10^{\circ} \mathrm{C}$, before rising again in April. The total rainfall was $2023 \mathrm{~mm}$ from April 2008 to March 2009 (Figure 1(b)), which was $6 \%$ higher than the long-term average.

\subsection{Dry Matter Yields and Quality}

The grass accessions produced between $23.5-67.0 \mathrm{t} \cdot \mathrm{ha}^{-1} \mathrm{DM}$, three to five times 
higher than the stylo accessions which produced $6.4-13.0 \mathrm{t} \cdot \mathrm{ha}^{-1}$ (Figure 2). The two stylo accessions behaved as annuals and died out during the first winter. They both were resown the following spring in April 2009. In the second year, DM yields of the stylo accessions were higher than the first year yields, but DM yields of the grass accessions were lower in the second year compared to the first year. Among the five grass accessions, Guimu- 1 hybrid elephant grass produced significantly the highest $(\mathrm{P}<0.05) \mathrm{DM}\left(67 \mathrm{t} \cdot \mathrm{ha}^{-1} \cdot \mathrm{yr}^{-1}\right), 122 \%$ and $92 \%$ higher than the paspalum accessions in 2008 and 2009 respectively. M II also produced significantly higher DM yields than the two paspalum accessions $(\mathrm{P}<0.05), 27 \%$ and 40\% higher in 2008 and 2009 respectively, but yielded similar levels to hybrid elephant grass. In the established year, paspalum from Thailand produced significantly higher DM than that from Hainan island, but not significantly different in the second year.

Crude protein levels of the two elephant grass accessions, two stylo accessions and M II were all over $10 \%$ at all cutting intervals, but the two paspalum averaged only 7.5\% (Table 1). Hybrid elephant grass yielded significantly higher levels of crude protein than the other grass accessions, which were similar to levels produced by Ubon stylo, however, Reyan 5 stylo from Hainan island yielded much less levels of crude protein but higher levels of fibre than Ubon stylo from Thailand. The two paspalum accessions produced the lowest crude protein but their leaf ratio was over $80 \%$, which was similar to M II and much higher than the elephant grass and stylo accessions (Table 1). M II produced high levels of crude protein, low fibre levels and a high percentage of leaf DM. Guimu-1 elephant grass produced significantly less proportion of leaf DM (52\%) than the other grasses in the study. Both stylo accessions had a lower proportion of leaf DM than the grasses (Table 1).

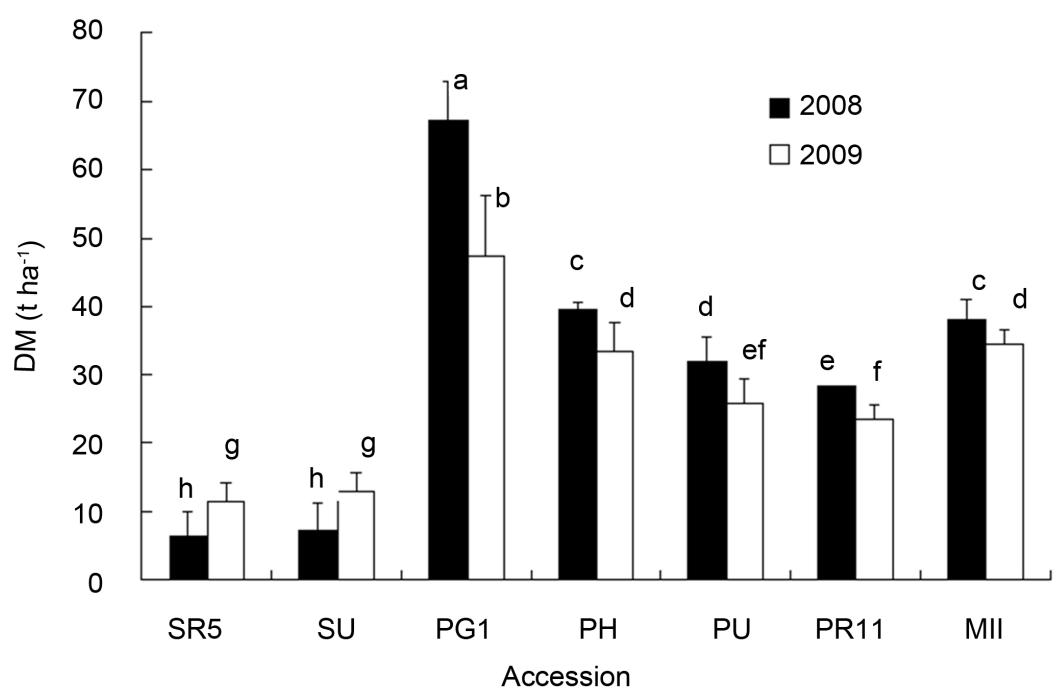

Figure 2. Dry matter yield of seven tropical forage accessions in 2008 and 2009. SR5 (Reyan 5 stylo), SU (Ubon stylo), PG1 (Guimu-1 hybrid elephant grass), PH (hybrid elephant grass), PU (Ubon paspalum), PR11 (Reyan 11 paspalum), MII (M II). Different lower case letters refer to significant at the 0.05 level under One-way ANOVA statistics. 
Table 1. Levels of crude protein, crude fibre and leaf ratio in seven tropical forage accessions.

\begin{tabular}{ccccc}
\hline Accession & Cutting time & $\begin{array}{c}\text { Crude protein } \\
(\%)\end{array}$ & $\begin{array}{c}\text { Crude fibre } \\
(\%)\end{array}$ & $\begin{array}{c}\text { Leaf DM ration \% } \\
\pm \text { CV\% }\end{array}$ \\
\hline Mulato II & August & 11.9 & 25.5 & \\
(M II) & November & 10.6 & 25.2 & $84.79 \pm 0.01$ \\
Reyan 2 paspalum & August & 8.0 & 27.8 & \\
(PR2) & November & 7.7 & 34.0 & $80.36 \pm 6.88$ \\
Ubon paspalum & August & 7.4 & 28.4 & \\
(PU) & November & 7.2 & 27.8 & $90.65 \pm 5.15$ \\
Guimu-1 hybrid & August & 10.3 & 29.2 & \\
elephant grass & November & 13.3 & 32.1 & $52.34 \pm 4.73$ \\
(PG1) & & 15.4 & 30.3 & \\
Hybrid elephant grass & August & 16.1 & 25.0 & $64.10 \pm 3.42$ \\
(PU) & November & 16.8 & 26.4 & $49.57 \pm 7.06$ \\
Ubon stylo (SU) & November & 11.0 & 34.1 & $47.82 \pm 8.16$ \\
\hline Reyan 5 stylo(SR5) & November & & & \\
\hline
\end{tabular}

\subsection{Photosynthesis}

Under a given $P P F D=1500 \mu \mathrm{mol} \cdot \mathrm{m}^{-2} \cdot \mathrm{s}^{-1}$, the net photosynthesis rates $\left(P_{\mathrm{n}}\right)$ of the seven accessions were all over $28 \mu \mathrm{mol} \cdot \mathrm{m}^{-2} \cdot \mathrm{s}^{-1}$, of which hybrid elephant grass and M II were over $42 \mu \mathrm{mol} \cdot \mathrm{m}^{-2} \cdot \mathrm{s}^{-1}$, followed by Guimu-1 hybrid elephant grass, Reyan 5 stylo, Ubon paspalum, Ubon stylo and Reyan 11 paspalum (Figure 3(a)). Stomatal conductance $\left(G_{\mathrm{s}}\right)$ of the two legume accessions was significantly higher than that of the grass accessions, while Gs of Guimu-1 hybrid elephant grass and Hybrid elephant grass was significantly higher than that of the other three grass accessions, (Figure $3(\mathrm{~b})$ ). The transpiration $\left(T_{\mathrm{r}}\right)$ of the two stylos was significantly higher than that of grasses, (Figure $3(\mathrm{c})$ ), resulting in their water use efficiency ( $W U E$ ) being significantly lower than the grasses, (Figure 3(d)); Tr of MII was higher than that of other four grass accessions, but it was no difference among paspalums and pennisetum. WUE of hybrid elephant grass was significantly highest followed by PG1, MII, PU and PR11. The photosynthesis-light curve analysis of the five grasses resulted in the M II curve on the top, followed by hybrid elephant grass, Guimu-1 hybrid elephant grass, Ubon paspalum and Reyan 11 paspalum (Figure 4(a)); The maximum value of net photosynthesis was highest in M II, followed by the two hybrid elephant grass accessions and the two paspalum accessions (Figure 4(b)). Light saturation points ( $L S P$ ) of M II and the two hybrid elephant grasses were much higher than the paspalum accessions (Figure 3(b), Figure 4(c)).

\subsection{Cold Tolerance and Winter Survival}

None of the stylos survived after the winter. Reyan 11 paspalum survived better than the other accessions in all three treatments (Figure 5). The survival rates of Reyan 11 paspalum under plastic cover and control treatments were not differ- 


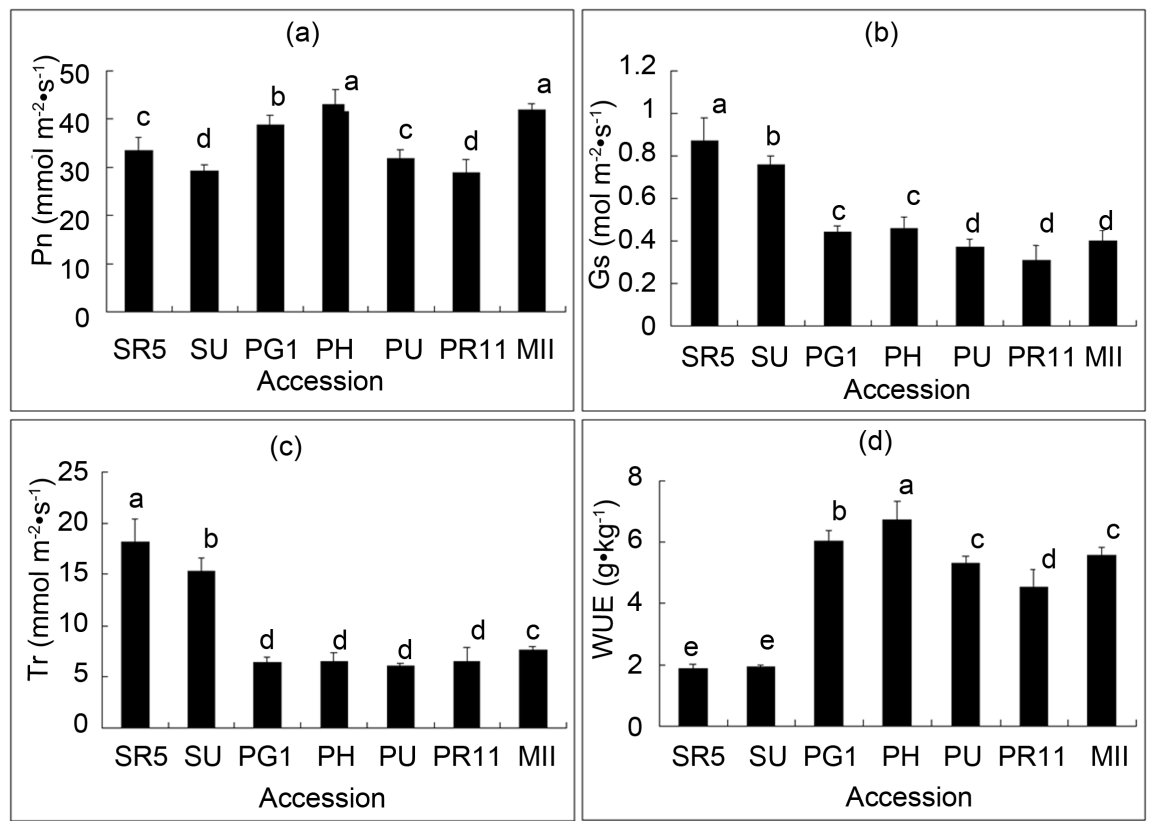

Figure 3. Photosynthesis characters of 7 tropical forage accessions at a given PPFD of $1500 \mu \mathrm{mol} \cdot \mathrm{m}^{-2} \cdot \mathrm{s}^{-1}$. SR5 (Reyan 5 stylo), SU (Ubon stylo), PG1 (Guimu-1 hybrid elephant grass), PH (hybrid elephant grass), PU (Ubon paspalum), PR11 (Reyan 11 paspalum), MII (M II). $P_{\mathrm{n}}$ refers to net photosynthesis rate, $G_{\mathrm{s}}$ to stomatal conductance, $T_{\mathrm{r}}$ to transpiration rate, WUE to water use efficiency. Different letters refer to significant at the 0.05 level under One-way ANOVA statistics.

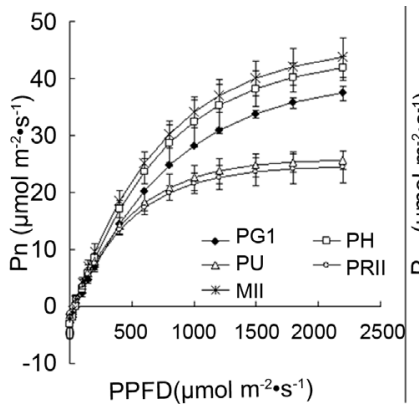

(a)

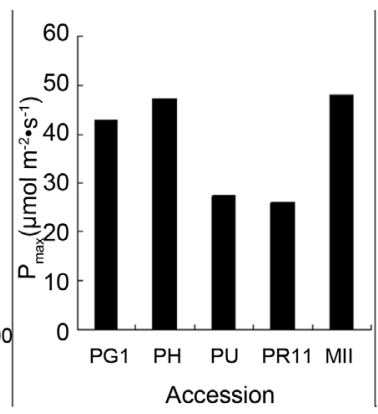

(b)

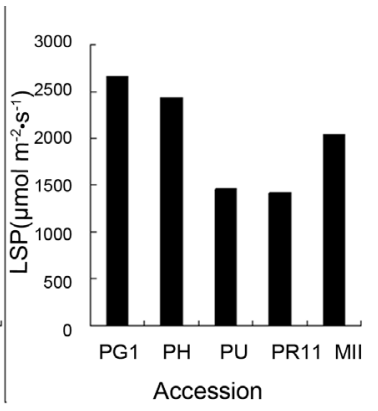

(c)

Figure 4. Photosynthetic rate response to PPFD of 5 grass Accessions. PG1 (Guimu-1 hybrid elephant grass), PH (hybrid elephant grass), PU (Ubon paspalum), PR11 (Reyan 11 paspalum), MII (Mulato II).Where $P_{\mathrm{n}}$ : net photosynthetic rate, $P_{\max }$ : the asymptote of photosynthesis at high light, LSP. Light saturation point.

ent and were significantly higher than survival rates under the straw cover treatment. The survival rates of Guimu-1 hybrid elephant grass and hybrid elephant grass were also high under control management, $85 \%$ and $90 \%$ respectively (Figure 5). Survival rate of M II under plastic cover was $83.2 \%$, significantly higher than under straw covering (15.7\%) and control (5.8\%) treatments. Similarly, the survival rate of Ubon paspalum under plastic cover also increased compared to control and straw cover, but these latter two cover treatments were significantly higher than those of M II. Survival rate of paspalum from Hainan was higher than that from Thailand in different treatment, particularly under no 


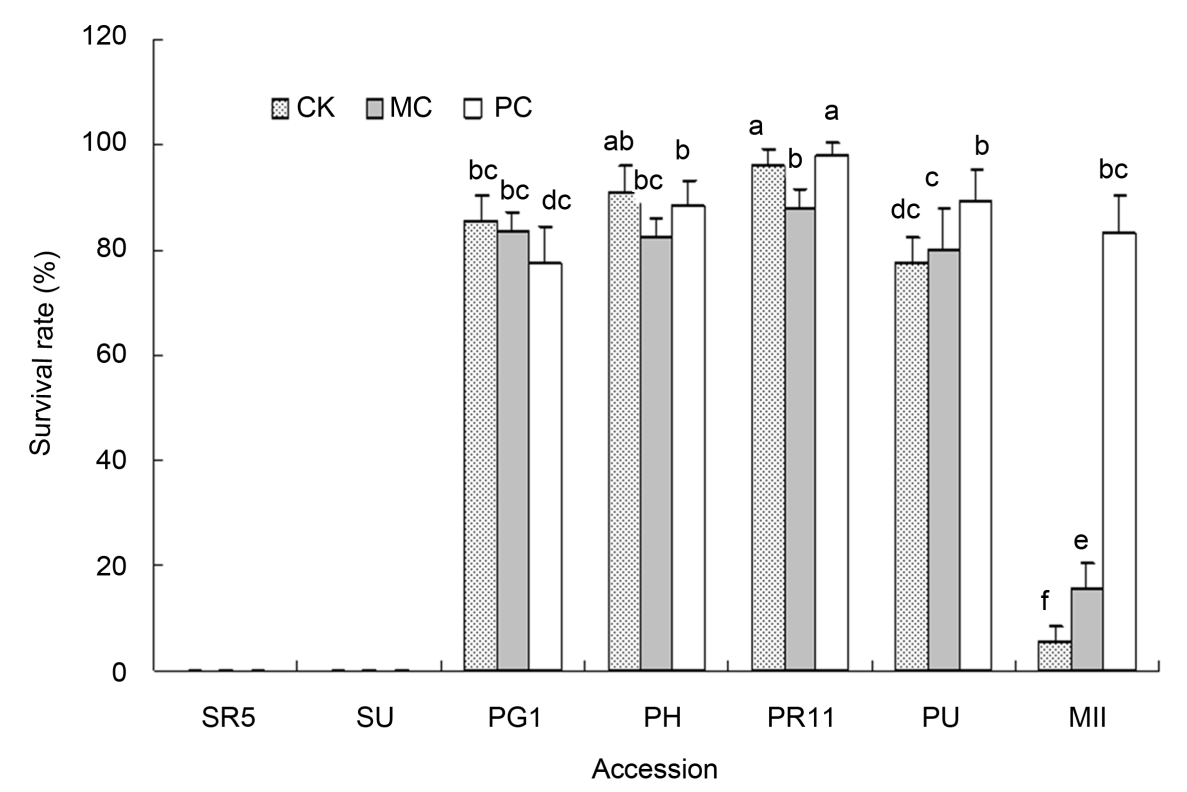

Figure 5. Survival rate after winter 2008-2009 under species and management treatments. CK: control, MC: grass and straw cover, PC: :plastic sheet cover. SR5 (Reyan 5 stylo), SU (Ubon stylo), PG1 (Guimu-1 hybrid elephant grass), PH (hybrid elephant grass), PU (Ubon paspalum), PR11 (Reyan 11 paspalum), Mulato II (M II).

cover treatment (CK).

\section{Discussion}

In subtropical areas of southern China, it has been short of native perennial pasture species with excellent quality. But the wet season coincidentally occurs in the hot summer provide an advantage condition for introducing tropical pasture species. However, low temperature (minor degree occurs commonly) in winter would constrain to establish perennial pasture with good tropical species which needs persistence over years. In this study, productivity of all the accession are high. PG1 and PH elephant grass become widely grown in southern subtropical China due to their very high DM and protein content. Although the growing season is shorter than that in Thailand, DM of M II, PU, and SU were much higher than those reported at northeast Thailand [13] [15] [22]. The reason may be that sufficient heat, water and radiation at our subtropical site facilitate these plant to photosynthesize and produce biomass; Comparatively, at northeast Thailand, the long dry season from winter to early summer, and following long rainy and dully summer days which result in periodic water and radiation deficiency leading to photosynthesis and biomass reduction [15] [22]. With high leaf ratio and low fibre levels, M II and the two paspalum accessions present good digestive and palatable traits [14] [15]; they might produce smaller amounts of DM comparing to elephant grass but still making them promising summer accessions in southern China.

Photosynthesis variables consider to be indicators of productivity capacity. $P_{\max }$ of the 5 grass accession are high. $P_{\max }$ of two elephant grass PG1 and PH is 
much higher than some other elephant grasses such as pearl millet (Pennisetum americanum L.) $\left(25 \mu \mathrm{mol} \cdot \mathrm{m}^{-2} \cdot \mathrm{s}^{-1}\right)$ [23], and common elephant grass (Pennisetum purpureum Schumach) $\left(<30 \mu \mathrm{mol} \cdot \mathrm{m}^{-2} \cdot \mathrm{s}^{-1}\right)$ [24]. PR11 and PU paspalum produce $P_{\mathrm{n}}$ in our study is compatible to $\mathrm{PR} 11$ paspalum $\left(28.8 \mu \mathrm{mol} \cdot \mathrm{m}^{-2} \cdot \mathrm{s}^{-1}\right)$ reported by Liu [25] at Zhanjiang, China but higher than bahia grass (Paspalum notatum Flügge) $\left(26 \mu \mathrm{mol} \cdot \mathrm{m}^{-2} \cdot \mathrm{s}^{-1}\right)$ by Ribeiro [26]. This results showing these introduced grass accessions presented a satisfied productivity capacity. The two stylos produce higher $P_{\mathrm{n}}$ than that under cooler and less radiation greenhouse condition [12], indicating stylos prefer to high radiation and hot temperatures. Therefore, subtropical summer is advanced for stylo to uptake $\mathrm{CO}_{2}$.

However, high photosynthesis does not always results into high DM [11]. Under natural conditions, DM obtained from photosynthesis may be influenced by many factors, e.g. LAI, radiation reaching the leaves, leaf temperature, air humility and soil conditions and fertility [27]. Our five grasses has high leaf area index (LAI, MII: $11.29 \pm 2.05$; PU: $8.01 \pm 1.25$; PR11: $7.82 \pm 1.5$; PG1:5.2 \pm 1.0 ; PH:4.04 \pm 1.3 ), which may be a one reason to explain their high DM. DM/ $P_{\max }$ ratio could be referred to photosynthesis-biomass transfer rate. Range $\mathrm{DM} / P_{\max }$ ratio (Figure 6) did not fully consistence with range of DM (Figure 2) or $P_{\max }$ (Figure 4(b)). With highest $\mathrm{DM} / P_{\max }$ ratio, PG1 elephant grass obtained highest $\mathrm{DM}$ from high photosynthesis rate. However, due to its fair low $\mathrm{DM} / P_{\max }$ ratio, PU elephant grass obtain much less biomass than PG1 although it has similar photosynthesis rate and LAI. Meanwhile, with lowest $\mathrm{DM} / P_{\max }$ ratio among all the accession, M II obtain lower DM than PG1 even though it has higher photosynthesis rate and LAI. Additional reason could be that dense canopy of M II may block radiation reaching to leaves understory thereby reducing total photosynthetic production and hence producing lesser amounts of DM; furthermore, M II has a large root biomass (Eduardo Stern personal communication) and more root biomass implies less above ground DM [28].

High net photosynthesis may at the same time consume a lot of water from the soil by high stomatal openness [29]. In this study, although the transpiration rate of all 7 accessions were high, but the stomatal openness and transpiration rate of grass accessions were much less than of stylo accessions, thus the water use efficiency of the grass accessions were particular higher than that of the stylo accessions, indicating the grass accessions might adapt to less water condition.

When considering the persistence of a tropical species growing at subtropical zone, it is very important to understand if this species can tolerant to cold temperature below $0^{\circ} \mathrm{C}$. PG1 and PH elephant grass and PR11 paspalum had high survival rates without any cover management, suggesting they are good cold tolerance. Ubon paspalum may consider to be a medium cold tolerance accession as it could survive well under any either cover management. However, M II was very susceptive to cold, it could survival only under plastic cover management. In Florida, USA, M II was considerably weaken by winter cold temperatures below $0^{\circ} \mathrm{C}$ and recover slowly in the spring [3]. There is significant risk in using $\mathrm{M}$ 


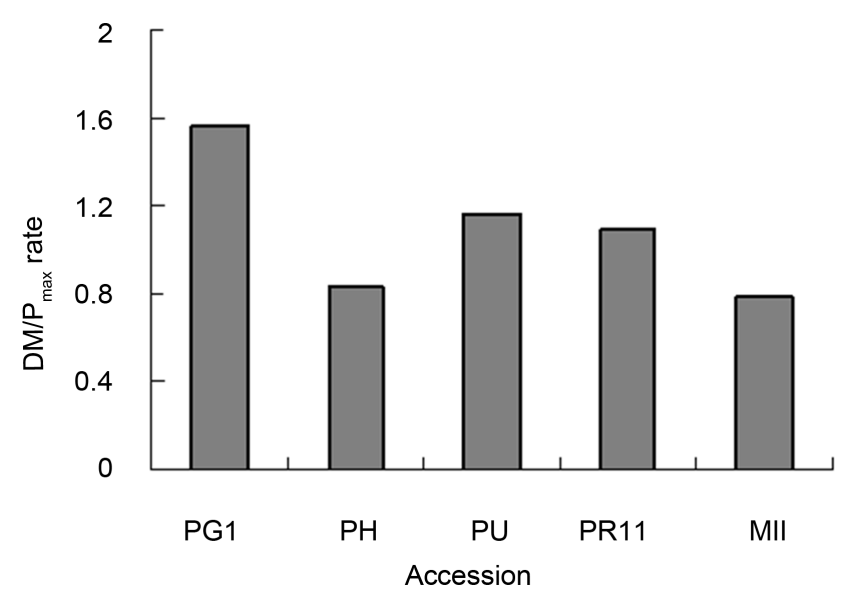

Figure 6. The ratio of Dry matter/Maximum net photosynthetic rate of the grass accessions. PG1 (Guimu-1 hybrid elephant grass), PH (hybrid elephant grass), PU (Ubon paspalum), PR11 (Reyan 11 paspalum), MII (M II).

II in perennial pasture systems. Therefore, in subtropical conditions, M II should be treated as an annual and be replanted every year.

To introduce legume forage accessions is very important as the number has been far from sufficient in subtropical region. In our study, although the summer DM of the two stylo accessions was high, but they succumbed to the winter cold with no plants survive during the winter. Some studies reported that some stylo accessions could survived in a mild winter cold subtropical sites [16] [17] [30]. SR5 presented most weaken to cold comparing to other stylo accessions such as GC1480, GC 1463 and Reyan 10 stylo [17] [30]. Therefore, SU and SR5 stylo should be treated as annuals and be replanted every year.

Accession trained in different climate condition may affect its cold tolerance. Two grass accessions PG1 and PH from Nanning (south subtropical) express the best cold tolerance, following PR 11 paspalum from Hainan(north tropical) and PU paspalum and M II from Ubon Ratchathani, Thailand (typical tropical). As Nanning, Hainan and Ubon Ratchathani locate in northern hemisphere decreasing with latitude, meaning their minimum temperature increase; thus we could conclude that trained in a cooler climate is possibly to result in better cold tolerance of an accession.

Different cover practice may influence on cold-susceptibility of a plant. Basing on the data of two weak cold-tolerance accessions PU and M II, we could speculate that plastic cover is significantly better than mass (straw) cover. The reason may be that: in mass cover management, the cold air could reach to the stubble by the inter space of the straw, while in plastic management, plastic could block the cold air from the stubble, as a result to delay the cold impact. Therefore, plastic cover may be better to protect the stubble.

\section{Conclusion}

Due to climate restrained, to evaluate a high production and good quality forage 
accession is an urgent practical problem in the subtropical region. Our study suggests that all 5 grasses could be used as summer forage as they produce high photosynthesis and mass production and good protein content. Two elephant grass PG1 and PH, and paspalum accession from Hainan are the most suitable species as perennial pastures in Guangxi subtropical region. However, the twostylo legume is not suitable for perennial because they are susceptible to winter cold. Paspalum trained in a cool climate zone before being introduced to subtropical region is recommended; but it needs some cover for winter management if introduced from warm climate such as Thailand when used for perennial parsture. M II has very high leaf proportion but sensitive to cold; it needs plastic cover during winter when used for perennial forage. Therefore, it is necessary to understand the accession's performance before planted in large scale.

\section{Acknowledgements}

This work was supported by the funds of the funds of the Guangxi Science and Technology (Gui Ke Zhong1598014-3, 2013GXNSFEA053001), Guangxi Chairman R\&D Funding (1324105), the Key Technologies R\&D Program of China's Ministry of Science and Technology (2012BAC16B01), and GXIB Funding (GuiZhiYe 14001). Special thanks are extended to Mr. David Bromwich, Mr. Tim Harvey and Professor Xie Jishi for their help in introducing the pasture seeds from Thailand, and to the China Meteorological Data Sharing Service System for providing the meteorological data.

\section{References}

[1] Alamo-Guarda, V.D. and Alamo-Guarda, R.D. (2014) Brazilian Tropical Grassland Ecosystems: Distribution and Research Advances. American Journal of Plant Sciences, 5, 924-932. https://doi.org/10.4236/ajps.2014.57105

[2] Hare, M.D., Tatsapong, P. and Phengphet, S. (2009) Herbage Yield and Quality of Brachiaria Cultivars, Paspalum atratum and Panicum maximum in North-East Thailand. Tropical Grasslands, 43, 65-72.

[3] Vendramini, J.M.B., Sollenberger, L.E., Lamb, G.C., Foster, J.L., Liu, K. and Maddox, M.K. (2012) Forage Accumulation, Nutritive Value, and Persistence of "Mulato II” Brachiaria Grass in Northern Florida. Crop Science, 52, 914-922.

[4] Liang, Y.C. (1999) Studies on Selection and Cultivation of Guimu-1 Hybrid Pennisetum purpureum. Grassland of China, 1, 19-22.

[5] Zhu, L.F., Jiang, H.D., Gao, Y., Zhong, X.X. and Cao, W.X. (2006) The Effects of Different Preceding Crops on Yield and Forage Quality of Pennisetum Hybrid. Acta Prataculturae Sinica, 2, 76-83.

[6] Hu, W.H, Zhou, Y.H., Du, Y.S., Xia, X.J. and Yu, J.Q. (2006) Differential Response of Photosynthesis in Greenhouse- and Field-Ecotypes of Tomato to Long Term Chilling under Low Light. Journal of Plant Physiology, 163, 1238-1246.

[7] Thomashow, M.F. (1998) Role of Cold-Responsive Genes in Plant Freezing Tolerance. Plant Physiology, 118, 1-7. https://doi.org/10.1104/pp.118.1.1

[8] Al-Shoaibi, A.A. (2008) Photosynthetic Response to Low Temperature in Elephant Grass (Pennisetum purpureum) and Zea mays. International Journal of Botany, 4, 309-314. https://doi.org/10.3923/ijb.2008.309.314 
[9] Wang, R.Z. and Ma, L. (2016) Climate-Driven C4 Plant Distributions in China: Divergence in C4 Taxa. Scientific Report. https://doi.org/10.1038/srep27977

[10] Edwards, E.J. and Still, C.J. (2008) Climate, Phylogeny and the Ecological Distribution of C4 Grasses. Ecology Letters, 11, 266-276.

https://doi.org/10.1111/j.1461-0248.2007.01144.x

[11] Larcher, W. (2001) Physiological Plant Ecology. 4th Edition, Verlag, Berlin Heidelberg, 91-101.

[12] Zhou, B.Y., Guo, Z.F. and Lin, L. (2006) Effects of Abscisic Acid Application on Photosynthesis and Photochemistry of Stylosanthes guianensis under Chilling Stress. Plant Growth Regulation, 48, 195-199.

[13] Hare, M.D., Saengkham, M., Kaewkunya, C., Tudsri, S. and Suriyajantratong, W. (2001) Effect of Cutting on Yield and Quality of Paspalum atratum in Thailand. Tropical Grasslands, 35, 144-150.

[14] Hare, M.D., Gruben, I.E., Tatsapong, P., Lunpha, A., Saengkkham, M. and Wongpichet, K. (2004) Inter-Row Planting of Legumes to Improve the Crude Protein Concentration in Paspalum atratum cv. Ubon Pastures in North-East Thailand. Tropical Grasslands, 38, 167-177.

[15] Hare, M.D., Tatsapong, P., Lunpha, A. and Wongpichet, K. (2005) Brachiaria Species in North-East Thailand: Dry Matter Yields and Seed Production. Tropical Grasslands, 39, 99-106.

[16] Liu, G.D., Bai, C.J., He, H.X., Wang, D.J. and Zhou, J.S. (2001) The Selection and Utilization of Stylosanthes guianenensis cv. Reyan No. 5. Acta Agrestia Sinica, 9, 1-7.

[17] Liu, G.D., Bai, C.J., Wei, D.J. and Yi, K.X. (2004) Stylosanthes Cultivars in China: Their Development and Performance. In: Chakraborty, S., Ed., High-Yielding Anthracnose-Resistant Stylosanthes for Agricultural Systems, ACIAR Monograph No. 111, ACIAR, Canberra, 153-158.

[18] Chinese National Standard GB/T6432-1994, GB/T 6433-2006 and GB/6434-2006. http://new.sac.gov.cn

[19] Peek, S.M., Russek-Cohen, E., Wait, D.A. and Forseth, I.N. (2002) Physiological Response Curve Analysis Using Nonlinear Mixed Models. Oecologia, 132, 175-180. https://doi.org/10.1007/s00442-002-0954-0

[20] McCarron, J.K. and Knapp, A.K. (2001) C3 Woody Plant Expansion in a C4 Grassland: Are Grasses and Shrubs Functionally Distinct? American Journal of Botany, 88, 1818-1823. https://doi.org/10.2307/3558358

[21] Smith, M.D. and Knapp, A.K. (2001) Physiological and Morphological Traits of Exotic, Invasive Exotic, and Native Plant Species in Tall Grass Prairie. International Journal of Plant Science, 162, 785-792. https://doi.org/10.1086/320774

[22] Hare, M.D. (2007) Successful Seed Production of South American Forages in Ubon Ratchathani Province, Thailand: Research, Development and Export. In: Hare, M.D. and Wongpichet, K., Eds., Forages. A Pathway to Prosperity for Smallholder Farmers, Proceedings of an International Forage Symposium, Faculty of Agriculture, Ubon Ratchathani University, Thailand, 35-60.

[23] Da Matta, F.M., Loos, R.A., Odrigues, R. and Raimundo, S. (2001) Actual and Potential Photosynthetic Rates of Tropical Crop Species. Revista Brasileira de Fisiologia Vegetal, 13, 24-32. https://doi.org/10.1590/S0103-31312001000100003

[24] Al-Shoaibi, A.A. (2008) Photosynthetic Response of Elephant Grass (Pennisetum purpureum) to $\mathrm{NaCl}$ Salinity. Journal of Biological Sciences, 8, 610-615. https://doi.org/10.3923/jbs.2008.610.615 
[25] Liu, J.X., Chen, W.Y. and Xiao, S.H. (2009) A Study on the Photosynthetic Characteristics of Paspalum atratum. Acta Prataculturae Sinica, 18, 254-258.

[26] Ribeiro, R.V., Lyra, G.B., Santiago, A.V., Pereira, A.R. and Machado, E.C. (2006) Diurnal and Seasonal Patterns of Leaf Gas Exchange in Bahiagrass (Paspalum notatum Flügge) Growing in a Subtropical Climate. Grass and Forage Science, 61, 293 303. https://doi.org/10.1111/j.1365-2494.2006.00533.x

[27] Jiang, G.M., Chang, J., Gao, Y.B. and Li, Y.G. (2004) Plant Ecophysiology. Higher Education Press of China, Beijing, 81-82, 144-150.

[28] Gindaba, J., Rozanov, A. and Negash, L. (2005) Photosynthetic Gas Exchange, Growth and Biomass Allocation of Two Eucalyptus and Three Indigenous Tree Species of Ethiopia under Moisture Deficit. Forest Ecology and Management, 205, 127-138.

[29] Kang, S.Z., Shi, W.J., Hu, X.T. and Liang, Y.L. (1998) Effects of Regulated Deficit Irrigation on Physiological Indices and Water Use Efficiency of Maize. Transactions of the Chinese Society of Agricultural Engineering, 14, 82-87.

[30] Bai, C.J., Liu, G.D. and Wang, D.J. (2004) Selecting High-Yielding AnthracnoseResistant Stylosanthes in Hainan. In: Chakraborty, S., Ed., High-Yielding Anthracnose-Resistant Stylosanthes for Agricultural Systems, ACIAR Monograph No. 111, ACIAR, Canberra, 143-151.

Scientific Research Publishing

\section{Submit or recommend next manuscript to SCIRP and we will provide best} service for you:

Accepting pre-submission inquiries through Email, Facebook, LinkedIn, Twitter, etc. A wide selection of journals (inclusive of 9 subjects, more than 200 journals)

Providing 24-hour high-quality service

User-friendly online submission system

Fair and swift peer-review system

Efficient typesetting and proofreading procedure

Display of the result of downloads and visits, as well as the number of cited articles

Maximum dissemination of your research work

Submit your manuscript at: http://papersubmission.scirp.org/

Or contact as@scirp.org 